\title{
VIOLÊNCIA DOMÉSTICA CONTRA A MULHER NA SOCIEDADE BRASILEIRA: CONTROVÉRSIAS EM TORNO DAS ESTRATÉGIAS DE CONTROLE DA CRIMINALIDADE FAMILIAR NO BRASIL
} DOMESTIC VIOLENCE AGAINST WOMEN IN BRAZILIAN SOCIETY: CONTROVERSIES AROUND THE STRATEGIES OF FAMILY CRIMINALITY CONTROL IN BRAZIL

Ricardo Freitas ${ }^{1}$

Faculdade Damas da Instrução Cristã

\section{Resumo}

A violência de gênero e, em particular, a violência doméstica, tornou-se nas últimas décadas um dos principais itens da agenda feminista de luta contra a sociedade patriarcal. Tendo adotado uma perspectiva eminentemente punitivista em relação ao homem autor de violência, o feminismo colide com a visão das correntes políticocriminais e criminológicas abolicionistas e adeptas do direito penal mínimo. Este artigo pretende evidenciar a complexidade do problema e propor ao mesmo tempo, em consonância com o garantismo penal, uma política criminal adequada ao controle das diversas espécies de violência doméstica.

Palavras-chave

Patriarcalismo. Violência de Gênero. Violência Doméstica. Criminalização. Estratégias Político-Criminais. Justiça Restaurativa.

\section{Abstract}

Gender-based violence, and in particular domestic violence, has in recent decades become one of the main issues on the feminist agenda in the fight against patriarchal

${ }^{1}$ Professor do Programa de Pós-graduação da Faculdade Damas da Instrução Cristã. Professor de Direito Penal da Faculdade de Direito do Recife, da Universidade Federal de Pernambuco (UFPE). 
society. Having adopted an eminently punitive perspective in relation to the male perpetrator of violence, feminism clashes with the view of political-criminalist and criminological abolitionist currents and adherents of minimum criminal law. This article intends to highlight the complexity of the problem and to propose at the same time, in accordance with the liberal criminal law, a suitable criminal policy for the control of the various types of domestic violence.

Keywords

Patriarchy. Gender Violence.Domestic Violence. Criminalization. PoliticalCriminal Strategies. Restorative Justice.

\section{INTRODUÇÃO: COMPLEXIDADE E DIMENSÃO DA CRIMINALIDADE DOMÉSTICA COMO EXPRESSÃO DA VIOLÊNCIA DE GÊNERO.}

Historicamente, a problemática da violência de gênero foi introduzida na agenda política graças aos esforços empreendidos pelo movimento feminista a partir do início dos anos setenta do século passado. Baseando-se na constatação irrefutável de que as mulheres ocupam um lugar subordinado na sociedade desde tempos imemoriais em razão da cultura patriarcal, o movimento feminista dedica-se a lutar para que as mulheres se libertem dessa subordinação e para reconstruir a sociedade com base no princípio da igualdade de gênero. ${ }^{2}$

${ }^{2} \mathrm{O}$ conceito de gênero não se confunde com o conceito de sexo. Este último é um conceito puramente biológico, pois diz respeito ao domínio da natureza e não da cultura. Enquanto o sexo se refere à condição biológica de macho ou fêmea (homem ou mulher na linguagem universalmente aceita), o gênero é uma construção social ou cultural. O conceito de gênero é particularmente importante para o movimento 
Uma das manifestações mais óbvias, incisivas e cruéis da subordinação feminina é, sem dúvida, a violência masculina exercida contra as mulheres, ou seja, a violência de gênero. ${ }^{3} \mathrm{O}$ movimento feminista tem plena consciência de que a violência de gênero é uma das mais significativas expressões da cultura patriarcal, daí a necessidade de combatê-la. No sistema social patriarcal - ou, simplesmente, patriarcado - instituições e estruturas sociais favorecem a existência e reprodução das relações de gênero caracterizadas pela desigualdade bem como pela subordinação das mulheres aos homens. Este sistema social, compatível com as diversas formas de Estado, de governo e regime político, assegura a superioridade masculina e ao mesmo tempo estimula a opressão exercida sobre as mulheres mediante a distribuição não equitativa das oportunidades de acesso à riqueza, status e poder político. Em suma, todas as instituições que integram a espinha dorsal do patriarcado (família, Igreja, instituições estatais etc.) existem com o objetivo de assegurar a dominação

feminista porque é usado com a finalidade de demonstrar que a subordinação da mulher na sociedade contemporânea não tem fundamento biológico, mas explica-se por fatores de ordem sociocultural. Para as feministas isso significa que o atual status socioeconômico, político e cultura desfavorável da mulher pode perfeitamente ser modificado para melhorar sua condição, inclusive no que diz respeito às suas relações familiares, âmbito de sua existência no qual se produz a violência doméstica.

${ }^{3}$ Violência de gênero é "a exercida pelos homens contra as mulheres na qual o gênero do agressor e o da vítima estão intimamente unidos à explicação da dita violência. Dessa forma, afeta às mulheres pelo simples fato de ser do sexo feminino, ou seja, é a violência que os homens perpetram para manter o controle e o domínio sobre as mulheres" (Casique; Furegato, 2006). 
masculina em detrimento da mulher, incluindo as jurídicas, a exemplos das que fazem parte do sistema penal. A esse respeito, Bordelón (2003:452) afirma que "O Direito Penal do século XIX e de boa parte do século XX contribuiu para estabelecer e reproduzir um determinado significado do ser social mulher, ou seja, da estrutura de gênero". A autora recorda que, no Direito histórico, por um lado "a mulher aparece considerada como uma pessoa sujeita à tutela e sem plena responsabilidade; e por outro, estabelece um conjunto de controles sociais sobre a sexualidade feminina (criminalização do aberto ou da prostituição) e um conjunto de estereótipos sobre a sexualidade".

Percebe-se assim a razão pela qual o movimento feminista não aceita o ponto de vista de que a violência de gênero, inclusive a doméstica, decorre de problemas individuais de ordem biológica e/ou psicológica que acometem o agressor. Para as feministas, a violência de gênero é uma questão estrutural, pois radica na natureza da própria sociedade patriarcal, o que explica seu caráter generalizado, sistemático e padronizado (Giddens, 2010:117-119). ${ }^{4}$

${ }^{4}$ Embora para as feministas seja evidente que o agressor é o "homem biológico", é igualmente claro para elas que a violência de gênero é condicionada por fatores socioculturais. Isto significa que a violência masculina não é um problema psicológico-individual, mas tão-somente uma dentre as múltiplas expressões das relações de poder assimétricas que caracterizam sociedade patriarcal contemporânea. Consequentemente, para o feminismo o desafio não consiste propriamente em saber o que fazer com os homens violentos, mas em definir as medidas que devem ser adotadas com o fim de eliminar as manifestações violentas da masculinidade. Em outras palavras, o movimento feminista não pretende contribuir para o tratamento 
A dimensão da violência de gênero no Brasil impressiona. O número de mulheres vítimas de homicídio passou de 1.353 (1980) para 4.762 (2013) com um aumento de $252 \%$ no período. Nesses 23 anos, 106.093 mulheres foram assassinadas. Considerando o aumento da população feminina no intervalo de tempo indicado, o índice de letalidade ( 2,3 vítimas por 100 mil habitantes em 1980 e 4,8 em 2013) teve um aumento real de 111\% (Waiselfisz, 2015:11). Uma outra pesquisa igualmente abrangente apurou que o número de mulheres

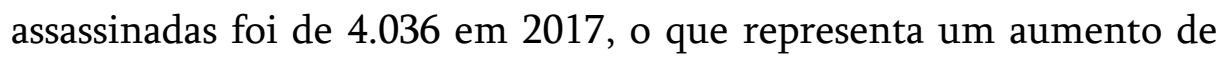
30,7\% de 2007 a 2017 (6,3\% entre 2016 e 2017). No primeiro ano da série foram cometidos 3,9 homicídios para cada 100 mil mulheres, tendo este número alcançado o patamar de 4,7 no último ano com um crescimento de 20,7\% (Cerqueira; Bueno, 2019:35). A conclusão é clara: o número de homicídios contra mulheres, que é a modalidade mais grave de violência de gênero, experimentou um aumento constante nas últimas quatro décadas, tornando-se um grave problema de saúde pública. ${ }^{5}$

psicológico dos agressores, mas almeja "a transformação das condições sociais que permitem a existência de uma estrutura de gênero desigual e o desenvolvimento dos direitos e liberdades das mulheres (Bordelón, 2003:479).

5 O Brasil é o quinto país mais violento dentre 83 nações quando se trata de assassinatos de mulheres. Somente El Salvador, Colômbia, Guatemala e Rússia estão em pior situação. Mata-se 48 vezes mais mulheres no Brasil que no Reino Unido, 24 vezes mais do que na Dinamarca ou na Irlanda e 16 vezes mais do que no Japão ou na Escócia (Waiselfisz, 2015:31). Em 2013, a média de homicídios de mulheres nos 83 países investigados chegou a 2,0 por 100 mil habitantes, ao passo que no Brasil foi de 4,8 mortes (Waiselfisz, 2015:75). 
Um olhar transversal direcionado à violência de gênero na modalidade homicídio :também revela que a letalidade característica deste crime afetou desproporcionalmente mais as mulheres negras que as brancas, haja vista que $40 \%$ das vítimas integraram o primeiro grupo (Cerqueira; Bueno, 2019:39). Calculando-se o nível de vitimização das mulheres negras em comparação com o das brancas, tem-se como resultado que, em 2003, a porcentagem de mortes das primeiras era $22,9 \%$ maior que a das segundas; em 2013, porém, morreram $66,7 \%$ mulheres negras a mais que as brancas (Waiselfisz, 2015:36). ${ }^{6}$ Significa que no que concerne à violência de gênero a vulnerabilidade da mulher negra é maior que a da mulher branca em nosso país, o que também ocorre nos Estados Unidos (Silveira; Nardi; Spindler, 2014:330).

Significativa quantidade de mulheres tem sido assassinadas por seus companheiros, o que representa um grande desafio tanto para o movimento feminista como para o sistema penal. A violência doméstica contra mulheres, expressão particular da violência de gênero, não se resume aos homicídios cometidos contra elas por seus esposos, companheiros e namorados, mas envolve uma ampla gama de comportamentos agressivos, alguns de natureza psicológica e

${ }^{6} \mathrm{O}$ número de mulheres brancas vítimas de homicídio caiu de 1.747 (2003) para 1.576 (2013) (-9,8\%), enquanto o de mulheres negras assassinadas subiu de 1.864 (2003) para 2.875 (2013) (+54,2\%). Levando em consideração o crescimento populacional, houve uma pequena diminuição da taxa de homicídio de mulheres brancas de 3,6 por 100 mil (2003) para 3,2 por 100 mil (2013). Em comparação, a taxa de assassinatos de mulheres negras subiu de 4,5 por $100 \mathrm{mil}$ (2003) para 5,4 por 100 mil (2013) (Waiselfisz, 2015:34-35). 
simbólica, dentre os quais apenas alguns são tipificados como infrações penais. $^{7}$

Somente entre 2015-2016 houve um aumento de 93,87\% no número de registros feitos por via telefônica que resultaram em 112.545 ocorrências de violência doméstica (Beiras; Nascimento; Incrocci, 2019:263). Estudo desenvolvido em uma unidade de saúde da cidade de São Paulo com 789 entrevistados homens revelou que nada mais nada menos que $31,9 \%$ deles havia cometido algum tipo de violência física contra suas parceiras íntimas, sendo que 3,9\% tinham praticado violência sexual (Madureira, 2014:601).

Frente ao mencionado desafio, indaga-se: tomando como base o Direito Penal e o Direito Processual Penal de garantias, quais estratégias político-criminais de controle desses comportamentos desviados teriam maior possibilidade de produzir resultados mais favoráveis aos interesses das mulheres sem afetar ou, em termos mais

7 'Pesquisadores consideram amiúde que a violência intrafamiliar, a violência ocorrida no trabalho e a violência doméstica são modalidades de violência de gênero (Casique; Furegato, 2006), porém, evidentemente este modo de pensar não é correto, pois estas modalidades de violência de gênero podem ter como agressores e vítimas não só mulheres, mas também homens e crianças. Portanto, somente quando a violência doméstica tem mulheres como vítimas é que pode ser considerada uma das inúmeras manifestações da violência de gênero. Laurenzo (2008:2097) esclarece acerca dessas duas categorias de violência frequentemente confundidas: "Enquanto a violência doméstica encontra sua explicação nas relações assimétricas próprias da estrutura familiar e pode afetar tanto os homens como as mulheres; a violência de gênero mergulha suas raízes na discriminação estrutural do sexo feminino própria da sociedade patriarcal e, por isso, suas vítimas são sempre as mulheres". 
realistas, afetando na menor medida possível tanto os direitos das próprias vítimas quanto os de seus agressores?

Há consideráveis discordâncias acerca das estratégias político-criminais que seriam mais adequadas ao controle da violência doméstica contra as mulheres. De acordo com a visão convencional sobre o problema ora em discussão, historicamente as lutas feministas contra a dominação masculina conceberam acertadamente a violência de gênero e, em particular, a violência doméstica como expressão fundamental da subordinação social e cultural da mulher na sociedade patriarcal e abraçaram uma estratégia de combate ao problema caracteristicamente punitivista. Ainda de acordo com a opinião convencional, em sentido diametralmente oposto ao ponto de vista feminista, juristas e profissionais do direito abolicionistas e defensores do minimalismo penal defenderam o emprego de medidas não punitivistas destinadas ao controle da criminalidade violenta masculina (Larrauri, 1992). ${ }^{8}$

${ }^{8}$ A narrativa de Larrauri (1992) acerca do caráter punitivista da visão feminista no tocante à violência de gênero é contraditada pela afirmação de Bordelón (2003:480) de que o movimento feminista se dividiu diante da estratégia a ser adotada para combater as agressões cometidas pelos homens contra as mulheres. Embora Bordelón admita que desde os anos setenta a criminalização das agressões sexuais e da violência familiar em defesa da mulher se tornou uma das bandeiras de parte do movimento feminista, ela ressalva que o feminismo dividiu-se quanto a essa estratégia. A autora afirma que uma parcela do movimento tinha ressalvas em relação à tática punitivista por terem consciência das insuficiências da intervenção penal e das contradições que acarretava. 
Em nosso país a divergência político-criminal teria se verificado não apenas entre feministas e profissionais do direito, mas também entre aquelas e profissionais de outras áreas do conhecimento. ${ }^{9}$ Romeiro (2009:49) diz a respeito que o processo legislativo que culminou na promulgação da Lei "Maria da Penha" opôs o movimento feminista, então representado por seis organizações não-governamentais, aos chamados operadores jurídicos.

Sem querer negar a existência de dois campos que tendem a ser opostos (feministas versus operadores jurídicos), acreditamos que o conflito entre aqueles que pretendem exacerbar as punições contra os homens agressores e aqueles que não desejam fazê-lo por uma série de razões merece ser analisada de maneira menos convencional. Certamente muitos profissionais do direito devem ter assumido o viés punitivista adotado pelo movimento feminista em relação à violência de gênero. ${ }^{10}$ Neste sentido, o próprio Romeiro (2009:57) reconhece no

${ }^{9}$ Neste texto, a expressão política-criminal é utilizada em sentido amplo, isto é, como sinônimo de política social e não em sentido estrito, ou seja, com o significado de política-penal. Em sentido amplo, a política-criminal inclui não apenas estratégias extrajurídicas e extrapenais de controle da criminalidade, mas também a políticapenal.

10 A natureza polêmica do debate acerca das estratégias de enfrentamento do problema da violência de gênero é reconhecida por Beiras, Nascimento e Incrocci (2019:271). Segundo eles, "o debate sobre gênero, masculinidades e violência doméstica e de gênero, ainda é recente no Brasil, e não está isento de tensões e contradições por parte de setores sociais, como aqueles vinculados ao movimento social organizado, ou mesmo entre acadêmicos e acadêmicas de diferentes filiações teóricas. De igual maneira, o lugar do homem na dinâmica conjugal e nas relações de gênero também aponta para um debate permeado por polêmicas, sobretudo no que 
tocante à utilização do Direito Penal como instrumento de proteção da mulher em nosso país que "mesmo com as controvérsias existentes os operadores jurídicos reconhecem sua validade enquanto uma forma de coibir a 'violência conjugal'" e, consequentemente, defendem o "aumento da punição e da possibilidade de encarceramento para os homens autores da violência".

Portanto, os profissionais do direito não se posicionaram de maneira uniforme a respeito do uso do Direito Penal para a proteção da mulher contra a violência doméstica, o que não deixa de ser um reflexo da variedade de ideologias penais que influenciam mundo jurídico brasileiro. Do mesmo modo, a unanimidade também não se fez presente no campo feminista. Contudo, para os efeitos desta reflexão admitiremos a existência de dois campos radicalmente opostos apenas para facilitar a exposição do problema em exame e o desenvolvimento de nossa argumentação.

Aqueles que defendem o emprego rigoroso do Direito Penal contra os homens que praticam violência doméstica contra mulheres geralmente o fazem com base em argumentos que materializam concepções tradicionais de justiça. Em nossa perspectiva estas concepções de justiça não podem nem devem ser inteiramente desprezadas como pretendem, sobretudo, mas não apenas, as correntes abolicionistas. Porém, acreditamos ao mesmo tempo que na grande maioria dos casos a violência doméstica deve ser alvo de uma política

se refere a perspectivas mais punitivistas ou outras que advogam pela importância da ressignificação das masculinidades como aporte fundamental para relações mais equitativas e, consequentemente, menos violentas. 
criminal menos e não mais punitivista. Em síntese, partiremos de uma exposição sucinta do problema da violência doméstica para em seguida examinarmos as diferentes concepções político-criminais destinadas a sua contenção. Por fim, ofereceremos o esboço de uma alternativa de controle da violência doméstica contra as mulheres com vistas a impedir sua reprodução que consideramos garantista e equilibrada.

Este artigo é inaugurado com uma exposição problematizada acerca das estratégias político-criminais de controle da violência doméstica adotadas no Brasil. Em seguida, trata das alternativas estratégicas que o sistema penal nacional pode adotar para tutelar os direitos das mulheres diante da violência doméstica. Por fim, o terceiro capítulo abriga uma reflexão acerca das opções políticocriminais mais adequadas ao enfrentamento do problema objeto de estudo. Evidentemente, muitas questões abordadas não são passíveis de aprofundamento neste texto em razão de sua reduzida extensão. Esperamos, entretanto, que sua menção possa servir para inspirar ulteriores investigações.

\section{ENTRE PUNIR E RESSOCIALIZAR: A CONCEPÇÃO FEMINISTA E A ESTRATÉGIA POLÍTICA-CRIMINAL DE CONTENÇÃO DA VIOLENNCIA DOMÉSTICA NO BRASIL.}

O feminismo compreende acertadamente que a modernidade instituiu duas esferas sociais diferentes e separadas entre si: a esfera pública, na qual predominam regras de conduta social que consagram a impessoalidade e a universalidade; e a esfera privada, espaço destinado à preservação da vida íntima e das relações de natureza pessoal. A esfera pública é o âmbito no qual a cidadania é exercida com base em pautas de comportamento e valores 
compartilhados. Portanto, é na esfera pública que o homem se realiza plenamente enquanto ser político. Por seu turno, a esfera privada é um ambiente imune à intervenção estatal. Numa sociedade liberal, o Estado assegura a individualidade eximindo-se de impor comportamentos e valores de natureza geral a esta ou aquela pessoa.

O problema decorrente dessa rígida separação entre esfera pública e esfera privada é que ela permite a existência de uma estrutura social contemporânea patriarcal que viabiliza a dominação masculina. A separação radical entre a esfera pública e a esfera privada acaba por permitir que o homem exerça uma autoridade ilimitada sobre a mulher, inclusive por meio da violência (Biroli, 2014:32). ${ }^{11}$ Portanto, dependendo da maneira como é encarada a relação entre a esfera pública e a esfera privada a postura do sistema penal no que tange à violência doméstica varia da mais completa indiferença à mais ampla e mais rigorosa intervenção possível por parte das instâncias oficiais (formais) de controle social, dentre as quais o sistema penal.

Reconhecendo o problema descrito nos parágrafos anteriores, nas últimas décadas do século passado o movimento feminista empreendeu campanhas contra a violência de gênero com o

${ }^{11}$ É indiscutível que a rígida separação entre a esfera pública e a esfera privada concorre para a violência doméstica contra a mulher. Basta observar que a quase totalidade dos crimes violentos cometidos contra os homens ocorrem no espaço público, ao contrário que ocorre com a grande maioria das mulheres, que são vitimizadas no próprio lar pelos seus companheiros. Portanto, enquanto para os homens sua casa é o lugar onde desfrutam de mais segurança, o oposto ocorre com as mulheres. Para elas, o próprio lar é lugar mais inseguro que existe (Madureira, 2014:606). 


\section{DELICTAE, Vol. 5, No8, Jan..-Jun. $2020 \mid 284$}

objetivo de evitar a impunidade dos agressores de mulheres. Opondose a essa estratégia eminentemente repressiva, seus críticos alegavam que ela não se destinava a prevenir crimes, mas a atender interesses puramente simbólicos. Segundo eles, as feministas pretendiam utilizar um direito penal reformado e reforçado contra os agressores não para reeducá-los no respeito às mulheres nem para impedi-los de cometer novos crimes, mas para denunciar a violência de gênero e, mais amplamente, a dominação machista característica da sociedade patriarcal. Desse modo, para os críticos da estratégia feminista "a complexa denúncia da violência de gênero foi vista de modo frequentemente simplificado e apresentada como uma simples exigência de repressão penal" (Bordelón, 2003:472).

Contudo, em que pese a crítica formulada tanto por setores do próprio feminismo como por juristas, o movimento feminista fez valer a ideia de que mais importante que retribuir com a pena as infrações penais caracteristicamente sexistas ou mesmo preveni-las em nome da tutela de bens jurídicos seria denunciar a violência masculina com a finalidade de debilitar a sociedade patriarcal para então transformá-la numa sociedade igualitária e, consequentemente, mais justa. Em suma, o movimento feminista abraçou a estratégia criminalizadora não porque acreditasse propriamente no funcionamento adequado do sistema penal, mas porque pretendia politizar o problema da violência de gênero através da via judicial. Do ponto de vista feminista, "criminalizar uma conduta como a violência familiar ou o estupro favoreceria o reconhecimento social amplo de sua negatividade social" e ao mesmo tempo contribuiria para ampliar a missão do Direito Penal que passava agora a atender demandas inéditas, sem esquecer a condenação do tratamento discriminatório 
que a legislação penal historicamente sempre conferiu às mulheres (Bordelón, 2003:481).

Em nosso país, o movimento feminista começou a organizar-se na década de setenta em um contexto político bastante diferente do europeu e americano. ${ }^{12}$ Se as mulheres europeias e americanas empreenderam a luta pela expansão de seus direitos em um ambiente democrático no qual o reconhecimento das liberdades não era mais posto em dúvida, o mesmo não ocorreu aqui. Por outro lado, na visão dos estudiosos do processo de organização feminista, o feminismo brasileiro revelou-se muito mais sensível às desigualdades sociais que o feminismo existente nos países centrais. Em consequência, uma preocupação com a sorte das mulheres socialmente desfavorecidas teria sido uma característica do feminismo nacional sem equivalente em outras paragens. Na agenda do movimento fez-se presente, assim, problemas relacionados não apenas à violência doméstica, mas também à saúde e ao trabalho das mulheres integrantes das camadas desfavorecidas da sociedade. No início da década de oitenta, o movimento feminista brasileiro já encarava a questão da violência doméstica como um problema social grave e logrou incluir o seu enfrentamento na agenda política nacional aproveitando-se da repercussão midiática de julgamentos nos quais os agressores foram

12 Em que pese a posição periférica do Brasil no mundo ocidental, a modernização conservadora empreendida nas décadas de 60 e 70 pelo regime militar tornou possível a expansão do ensino superior e o desenvolvimento das telecomunicações, facilitando assim o intercâmbio intelectual entre as ativistas brasileiras e estrangeiras de classe média (Moraes; Sorj, 2009:11-12). 
absolvidos de acusações de homicídio cometidos contra mulheres com base na tese da legítima defesa da honra (Moraes; Sorj, 2009:12-13). No Brasil, a pauta principal dos movimentos feministas incluiu a responsabilização dos agressores ou, mais precisamente, dos homens agressores (Beiras; Nascimento; Incrocci, 2019:263).

A modernização do país fez com que violência doméstica começasse a ser percebida pela sociedade como um problema grave a ser enfrentado. Graças ao feminismo as instituições começaram a modificar aos poucos sua visão sobre o problema da violência de gênero, haja vista que algumas a concebiam e ainda a concebem como um fenômeno anormal, como um desajuste psicológico na vida conjugal ou, em outras palavras, como um problema puramente individual caracterizado pela excepcionalidade e não como "um comportamento inscrito dentro do campo de possibilidades das relações de gênero" (Moraes; Sorj, 2009:13-14).

Foi na década de oitenta que governos estaduais submetidos às pressões feministas instalaram as primeiras "delegacias da mulher". Em São Paulo, o governo criou pioneiramente o Conselho Estadual da Condição Feminina em 1983. Dois anos depois, a primeira delegacia da mulher foi instalada na capital. No final da primeira década do século já existiam mais de 350 delegacias da mulher concentradas em apenas $10 \%$ dos municípios brasileiros, sendo $1 / 3$ no Estado de São Paulo (Moraes; Sorj, 2009:14).

Embora a criação das delegacias da mulher tenha representado um avanço na luta contra a violência doméstica, haja vista ter proporcionado um significativo aumento no número de notícias-crime, o fato é que os inquéritos policiais culminavam em arquivamento porque frequentemente as vítimas se retratavam, 
inviabilizando o prosseguimento das investigações policiais e, em consequência, a possibilidade de responsabilização penal do agressor (Romero, 2009:52; Moraes; Sorj, 2009:14). ${ }^{13}$

Dessa maneira, a realidade social encerrava um paradoxo: enquanto o movimento feminista pretendia combater a violência de gênero através dos sistema penal, as vítimas muitas vezes optavam amiúde por não fazê-lo, atitude que não se modificou sequer com o advento da Lei no 11.340/06 (Lei “Maria da Penha").

$\mathrm{Na}$ primeira metade da última década do século $\mathrm{XX}$ a violência de gênero tornou-se definitivamente um ponto importante na agenda internacional da luta pelos direitos humanos. Em junho de 1994 concluiu-se em Belém do Pará a Convenção Interamericana para Prevenir, Punir e Erradicar a Violência contra a Mulher, que entrou em vigor no dia 3 de março de 1995. Em agosto de 1996 ela foi promulgada (Decreto no 1.973, da Presidência da República).

A Convenção parte do reconhecimento de que a violência contra a mulher permeia toda a sociedade independentemente de classe social, raça ou grupo étnico, cultura, idade ou religião, afetando os direitos humanos, as liberdades, a igualdade e a dignidade das mulheres. Em seguida define a violência contra a mulher nos seguintes

${ }^{13}$ Moraes e Sorj (2009:14-16) constataram que as mulheres vítimas da violência recorriam às delegacias da mulher impulsionadas por "uma lógica diversa da lógica da instituição policial e da inspiração do movimento feminista, uma vez que a mais frequente motivação das mulheres em procurar as delegacias especializadas consiste em usar o poder policial para renegociar o pacto conjugal e não para criminalizar o parceiro" e também para que a polícia intimide o agressor ameaçando-o caso ele continue a se comportar violentamente. 
termos: "Qualquer ato ou conduta baseada no gênero, que cause morte, dano ou sofrimento físico, sexual ou psicológico à mulher, tano na esfera pública como na esfera privada" incluindo a violência física, sexual e psicológica "ocorrida no âmbito da família ou unidade doméstica ou em qualquer relação interpessoal, quer o agressor compartilhe, tenha compartilhado ou não a sua residência [...]". ${ }^{14}$ Quanto aos deveres impostos aos Estados constam, dentre outros, os seguintes: (1) agir com o devido zelo para prevenir, investigar e punir a violência contra a mulher; (2) adotar medidas jurídicas que impeçam o agressor de perseguir, intimidar ou ameaçar a mulher ou de fazer uso de meios que causem dano ou perigo de dano à vida, à integridade física e à propriedade da mulher; (3) assegurar o acesso da mulher à justiça e medidas de proteção em seu benefício; (4) assegurar a reparação do dano causado à mulher pelo seu agressor. Percebe-se, assim, que os mencionados deveres são em seu conjunto de natureza punitiva, protetiva, preventiva e reparatória.

Em meados dos anos noventa, isto é, na mesma época em que o governo brasileiro introduziu a Convenção no ordenamento jurídico nacional, entrou em vigor a Lei n 9.099, de 26 de setembro de 1995 que criou os juizados especiais cíveis e criminais cuja competência abrangia "a conciliação, o julgamento e a execução das

14 Portanto, a Convenção reconhece as múltiplas dimensões da violência contra a mulher, inclusive a psicológica. A respeito dessa espécie de violência de gênero, Pasinato (2015:421) assinala que "uma mulher pode ser humilhada por anos a fio, ou viver sob intenso controle de sua vida e sofrer severos danos à sua autoestima e saúde mental, sem que seu agressor nunca cometa um único gesto de violência física”. 
infrações penais de menor potencial ofensivo" (artigo 60, última parte). Ilícitos penais de menor potencial ofensivo foram definidos como contravenções penais e crimes cuja pena máxima não supere dois anos de privação da liberdade cumulada ou não com pena de multa (artigo 61). ${ }^{15}$

Romeiro (2009:52) recorda que antes da vigência da Lei no 9.099/95 os casos de violência doméstica eram "resolvidos" nas delegacias não especializadas ou nas delegacias da mulher. Portanto, é induvidoso que a Lei no 9.099/95 proporcionou em princípio uma ampliação do acesso à justiça em favor das vítimas da violência doméstica contra a mulher. Além disso, em tese, a possibilidade de suspensão do processo e da conciliação entre o agressor e a vítima deveria atender aos objetivos desta última que, como vimos anteriormente, já se manifestavam na esfera policial antes da criação dos juizados.

Rapidamente os crimes que traduziam violência contra as mulheres passaram a ser maioria nos juizados especiais criminais, o que favoreceu a publicização do problema. Porém, contrariando as pretensões feministas de castigar os homens agressores emergiu uma sensação de impunidade. Muitas vezes a conciliação entre as vítimas e os autores dos crimes pareciam ter sido produzidas mediante pressão

${ }^{15}$ Os princípios gerais que norteiam a Lei no 9.099/95 são os seguintes: oralidade, simplicidade, informalidade, economia processual e celeridade. Estes princípios são destinados a dinamizar a prestação jurisdicional mediante a diminuição dos custos processuais e do excesso de processos inconclusos, bem como a ampliar o acesso à justiça. 
exercida sobre as mulheres. Além disso, os operadores do sistema atuavam nas conciliações não a partir de uma perspectiva de gênero, mas de concepções tradicionalistas. Por último, os acordos resultavam bastante insatisfatórios para as vítimas, pois redundavam no pagamento de multas ou no fornecimento de cestas básicas. Consequentemente, na visão do movimento feminista os juizados especiais criminais transformaram-se em um fator de impunidade, relegitimando a violência masculina, desqualificando a pessoa da vítima e não proporcionando segurança contra agressões futuras. ${ }^{16}$ Além disso, a suspensão condicional do processo (artigo 89, da Lei no 9.099/95) era condicionada exclusivamente à vontade do infrator, desconsiderando completamente o interesse da vítima de violência doméstica na continuação do processo. Para as feministas, a suspensão condicional do processo nada mais seria que um instituto destinado a assegurar a impunidade do homem autor de violência. ${ }^{17}$

${ }^{16}$ Para as feministas, a ampliação do acesso à justiça proporcionada pelos juizados especiais criminais revelou "o despreparo de grande parte dos operadores jurídicos em lidar com a violência doméstica e familiar, fazendo-se notar a partir do grande número de conciliações coagidas e a desqualificação das vítimas durante os processos (Northaft; Beiras, 2019:5).

${ }^{17}$ A Lei no 9.099/95 admite seu compromisso com o Direito Penal mínimo ao afirmar em sua exposição de motivos: "A ideia de que o Estado possa e deva perseguir penalmente, sem exceção, toda e qualquer infração, sem admitir-se, em hipótese alguma, certa dose de discricionariedade ou disponibilidade da ação penal pública, mostrou com toda evidência sua falácia e hipocrisia". Coerentemente com esse espírito, a lei condicionou a instauração da ação penal pública à representação nos casos nela previstos e esforçou-se para evitar a aplicação da pena privativa de liberdade mediante a previsão de imposição de penas alternativas ao mesmo tempo 
Amplamente comemorada nos círculos jurídicos, a criação dos juizados especiais criminais colidiu diretamente com a pretensão feminista de aplicar punições penais exemplares aos homens autores da violência de gênero. No sentir do movimento feminista a Lei no 9.099/95 ia de encontro às exigências de criminalização da Convenção de Belém e às suas próprias visões sobre a política criminal relativa à violência de gênero.

Recordemos: historicamente o movimento feminista brasileiro defendeu reformas legislativas punitivistas. Portanto, para as feministas o tratamento benevolente concedido pelos juizados especiais criminais aos homens autores de violência doméstica era inaceitável por desconsiderar as peculiaridades deste tipo de violência e por não punir os agressores rigorosamente. Para o movimento feminista as penas alternativas à pena privativa da liberdade não tinham caráter punitivo. As feministas acreditavam que esse quadro era particularmente grave, considerando que a maioria dos processos em curso ou extintos nos juizados especiais criminais se referiam à violência doméstica, o que representaria uma violação da Convenção de Belém do Pará que, como vimos, havia sido incorporada ao ordenamento jurídico nacional. Enfim, esses problemas contribuíram em seu conjunto para que os Juizados especiais "fossem vistos pelas

em que estimulou a conciliação entre os sujeitos do delito e a reparação do dano. Por fim, a lei estabeleceu que nos crimes em que a pena mínima cominada fosse inferior a um ano o Ministério Público pudesse propor a suspensão do processo por dois a quatro anos desde que presentes certos requisitos. 
feministas como banalizadores e ineficazes no tratamento da violência conjugal" (Romeiro: 2009:54).

Nem sempre os profissionais do direito tendiam a concordar com o posicionamento do movimento feminista. É certo que muitos não simpatizavam com práticas que consideravam lenientes em relação ao comportamento dos agressores domésticos, a exemplo imposição de multa ou do fornecimento de cestas básicas; outros, porém, frequentemente amparados pelo entendimento de juristas liberais, argumentavam em sentido contrário às pretensões punitivistas do movimento feminista. Para estes últimos, a Lei no 9.099/95 representava um avanço na luta pelos direitos humanos porque evitava o encarceramento e, assim, a dessocialização do infrator. Dessa maneira, tanto o discurso feminista como o dos profissionais do direito e juristas que a ele se opunham "se referem aos direitos humanos como forma de legitimação de suas visões da questão da violência" (Romeiro, 2009:50). O conflito culminou com vitória do feminismo que, entretanto, não chegou a ser avassaladora e muito menos definitiva.

Aproximadamente uma década após a instalação dos Juizados especiais criminais entrou em vigor a Lei ㄲo 11.340/06, que subtraiu a competência dos Juizados para conhecer e julgar crimes que envolvessem violência doméstica contra a mulher (artigo 41). ${ }^{18}$ Ao mesmo tempo proibiu tanto a imposição de pena de pagamento de

18 "À suspensão condicional do processo e à transação penal não se aplicam na hipótese de delitos sujeitos ao rito da Lei Maria da Penha”. Súmula 536. STJ. Terceira Seção. J. 10/06/2015. DJE. 15/06/2015. 
cestas básicas como a substituição de pena que implique o pagamento isolado de multa (artigo 17). Ficou claro para todos que o legislador penal afastou-se do espírito da Lei no 9.099/95. Tratava-se agora de punir com maior rigor os agressores de suas esposas e companheiras. ${ }^{19}$

Tornou-se lugar comum considerar que o advento da Lei no 11.340, de 7 de agosto de 2006 representa uma vitória das mulheres na luta contra a violência doméstica e, mais ainda, em favor da igualdade de gêneros. Silveira, Nardi e Spindler (2014:325), dentre outros autores, acreditam que a mencionada lei "é um acontecimento que pode demarcar uma nova forma de legitimação de saberes que rompe com as formas cristalizadas de dominação masculina, pois afirma que qualquer ato violento contra a mulher é crime e violação dos direitos humanos". Tal entendimento, assaz generalizado, decorre sobretudo de alguns dispositivos da Lei "Maria da Penha". O artigo 7o, por exemplo, definiu de maneira bastante ampla cinco tipos de violência que podem ser cometidas contra a mulher: (1) física; (2) psicológica; (3) sexual: (4) patrimonial; (5) moral. Essas espécies de violência podem se manifestar de inúmeras maneiras. ${ }^{20}$

19 A Lei no 11.340/06 (Lei "Maria da Penha") tem como finalidade a criação de "mecanismos para coibir e prevenir a violência doméstica e familiar contra a mulher" nos termos estabelecidos pelo § 8을 do artigo 22, da Constituição da República e da Convenção de Belém do Pará (artigo 1o). A Lei "Maria da Penha” também proclama que a "violência doméstica e familiar contra a mulher constitui uma das formas de violação dos direitos humanos" (artigo 6o).

${ }^{20}$ Muitas vezes, é claro, as modalidades de violência aparecem combinadas. Assim, por exemplo, a violência física frequentemente é acompanhada pela psicológica ou pela moral. Casique e Furegato (2006) oferecem os seguintes exemplos de violência 
Em sua maior parte, as modalidades de condutas violentas descritas na Lei "Maria da Penha" traduzem comportamentos tipificados na legislação penal. Certas normas da Lei no 11.340/06 produziram consequências diretas na legislação penal. A alínea $f$, inciso II, do artigo 61, do Código Penal agrava os crimes cometidos "com abuso de autoridade ou prevalecendo-se de relações domésticas, de coabitação ou de hospitalidade, ou com violência contra a mulher na forma da lei específica" (artigo 43, da Lei no 11.340/06). ${ }^{21}$ Além

cometida contra a mulher no âmbito familiar: (1) abusos verbais com o objetivo de rebaixar, ridicularizar e insultar a mulher; (2) intimidação, a exemplo de olhares de advertência, gestos e gritos agressivos, arremesso e destruição de objetos pertencentes à mulher; (3) ameaças de matar, de ferir, de suicidar-se, de subtrair os filhos; (4) vigiar os passos da mulher, escutar sub-repticiamente suas conversas, impedi-la de fazer amizades ou de cultivar as antigas; (5) manifestar desprezo pela mulher tratando-a como inferior ou tomando decisões sem consultá-la; (6) controlar as finanças da mulher, impor-lhe recompensas e castigos monetários, não deixar que ela trabalhe etc.

${ }^{21}$ A avaliação doutrinária sobre a circunstância agravante genérica formulada na alínea $f$, inciso II, da Lei no 11.340/06 eventualmente pode ser bastante crítica, como pode ser observado na seguinte afirmação encontrada em conhecido manual de direito penal: "De ranço autoritário e sem qualquer justificativa plausível, é o fato de instituir-se sob o argumento de pretensa defesa da mulher uma presunção iuris et de iure de maior vulnerabilidade da vítima-mulher em sede probatória. No artigo 61, II, $f$, do Código Penal, estabeleceu-se uma absurda circunstância agravante baseada simplesmente no gênero feminino da vítima, considerada especialmente débil, com implicação de automática presunção de periculosidade do agente. Tal circunstância não diz respeito nem à magnitude do injusto, nem a magnitude da culpabilidade, tendo sido instituída, ao que parece, por razões político-criminais, totalmente desacertadas" (Prado, Carvalho, Carvalho, 2014:702). 
disso, o crime de lesão corporal praticado no contexto da violência doméstica (artigo 129, § 9o, do Código Penal) é descrito em um tipo derivado como "lesão for praticada contra ascendente, descendente, irmão, cônjuge ou companheira, ou com quem conviva ou tenha convivido, ou, ainda, prevalecendo-se o agente das relações domésticas, de coabitação ou de hospitalidade" e punido com pena de detenção, de 3 (três) meses a 3 (três) anos (artigo 44, da Lei no 11.340/06).

Acrescente-se que o artigo 45, da Lei no $11.340 / 06$ alterou o artigo 152, da Lei no 7.210/94 (Lei de Execução Penal) para acrescentar um parágrafo único determinando que "nos casos de violência doméstica contra a mulher, o juiz poderá determinar $\mathrm{o}$ comparecimento obrigatório do agressor a programas de recuperação e reeducação". ${ }^{22}$ Os referidos programas pretendem sensibilizar os agressores a respeito da "violência contra a mulher, buscando proporlhes outros modos de ser que não a tradicional divisão sexista, na qual de um lado está a parte frágil e de outro a parte forte e essa pode exercer sobre a outra seu poder, inclusive na forma de violência" (Medrado; Mello; Pimentel, 2008:84). Portanto, tratam-se de programas destinados a evitar a recidiva considerando-se que "a ocorrência de

${ }^{22}$ O dispositivo é criticado por Northaft e Beiras (2019:5): "Existe uma crítica pertinente quanto aos pressupostos que embasam esses objetivos. Por exemplo, por trás do prefixo 're' de 'reabilitação' e 'recuperação', está a ideia de que já existiu um momento em que os homens se relacionaram em igualdade com mulheres [...]. Se compreendermos que essa desigualdade de gênero é fomentadora da violência, não é possível buscar voltar a um estado - a partir da reabilitação, reeducação e recuperação - que nunca existiu”. 
violência contra a mulher nas relações familiares tende a se repetir ao longo da coexistência com o agressor e, quando não é refreada, pode evoluir e tornar-se mais danosa para a vítima" (Madureira, 2014:601).

Ignora-se o impacto efetivo produzido pela Lei "Maria da Penha" sobre a violência doméstica desde 2006 até o presente. Talvez alguns a considerem inócua por acreditar que ela nem eliminou nem reduziu significativamente a violência doméstica. Mas aparentemente essa hipótese é infirmada pelos dados. No período compreendido entre 1980 e 2006, isto é, antes da vigência da Lei "Maria da Penha", o crescimento do número de homicídio de mulheres perfazia $7,6 \%$ ao ano com crescimento de $2,5 \%$ ao ano, considerando-se, evidentemente, o tamanho da população feminina da época. Em comparação, no intervalo de tempo entre a promulgação da lei e o ano de 2013 o crescimento do número de homicídios de mulheres caiu para $2,6 \%$ ao ano com um aumento de $1,7 \%$ ao ano (Waiselfisz, 2015:11$12)$.

Mas esses dados, embora valiosos, são apenas um elemento a mais numa avaliação em torno da pertinência ou não de uma dada política criminal. Em primeiro lugar, porque se refere ao número de mulheres vítimas fatais da violência de gênero e não especificamente da violência doméstica. Depois, porque não é necessário ser sociólogo para compreender que as variações para cima ou para baixo nas taxas de criminalidade, mesmo quando estas se referem a crimes de homicídio, podem ser produzidas por inúmeros fatores dentre os quais a legislação penal é apenas um deles. Possivelmente, na melhor das hipóteses o Direito Penal é apenas um dos fatores com capacidade de afetar as taxas de criminalidade e, assim, tutelar efetivamente bens jurídicos. Fatores extrapenais e até mesmo extrajurídicos são 
considerados frequentemente pelas ciências sociais como mais importantes que os penais. Em terceiro lugar, porque a Lei "Maria da Penha" não criminaliza, mas apenas agrava o homicídio cometido contra mulheres, crime que continua tipificado no Código Penal. Em resumo, quando avaliamos os efeitos da Lei "Maria da Penha" devemos evitar o equívoco de acreditar que o fator decisivo da variação das taxas da criminalidade reside no funcionamento do sistema penal.

Considerando o percurso percorrido pelas mulheres na luta contra a violência de gênero e, em especial, contra a violência doméstica, seria o caso de examinarmos quais seriam as alternativas postas para lidar com um problema tão complexo e multifacetado e como elas são vistas tanto pelos seus críticos como pelos seus destinatários específicos: mulheres vítimas da violência doméstica e homens autores de violência doméstica contra as mulheres.

\section{AS ALTERNATIVAS ESTRATÉGICAS DO SISTEMA PENAL PARA ASSEGURAR A TUTELA DOS DIREITOS DA MULHER DIANTE DA VIOLÊNCIA DOMÉSTICA}

Quando discutimos quais seriam as melhores alternativas estratégicas destinada a tutelar mais efetivamente os direitos da mulher vítima da violência doméstica, não podemos deixar de registrar o esforço empreendido pelas diversas correntes criminologia crítica a partir da década de sessenta destinado a deslegitimar o sistema penal. Para ilustrar, tomemos como exemplo as conclusões da teoria do etiquetamento (Labeling approach).

Tendo constatado que nem todos os ilícitos penais são conhecidos pelas autoridades e, consequentemente, que nem todos os criminosos são processados, julgados e condenados, fenômeno conhecido como cifra oculta da criminalidade, a teoria do 
etiquetamento sustentou a tese de que a criminalização (primária e secundária) não passa de uma construção social. Isto significa que o indivíduo rotulado de criminoso é aquele que foi etiquetado como delinquente mediante um processo de seleção.

Um dos efeitos do mencionado processo de etiquetamento é a estigmatização da pessoa criminalizada cujos efeitos danosos são suficientemente conhecidos da Sociologia Criminal. Para os penalistas, a teoria do etiquetamento é desconcertante. Se de fato nem todo criminoso é identificado como infrator, mas apenas alguns recebem tal etiqueta isso significa que valores constitucionais muito caros ao Direito Penal não são observados pelo sistema penal, a exemplo da igualdade diante da lei, um dos pilares do Estado Democrático de Direito. Restaria então ao penalista crítico duas opções: enveredar pela estrada do abolicionismo radical ou tomar o caminho de um abolicionismo de cunho reformista interessado na adoção de estratégias de contenção minimalista da violência estatal mediante a contração progressiva da atuação do sistema penal. Esse panorama acarreta problemas tanto para as feministas como para os adeptos do Direito Penal mínimo.

Referindo-se às insuficiências da criminologia crítica diante da realidade social, Larrauri (1992) alude ao impacto causado na década de oitenta pelos novos movimentos sociais (ecologistas, feministas, pacifistas etc.) sobre as orientações teóricas que integram essa corrente criminológica. Em consequência desse impacto muitos criminólogos críticos, a exemplo dos marxistas, começaram a questionar se a deslegitimação do Direito Penal não teria ido longe demais, passando a defender a tese de que esse ramo do Direito deveria ser instrumentalizado em favor dos desfavorecidos quando, por 
exemplo, se tratasse de defender o meio-ambiente, de combater a delinquência econômica, de defender a mulher contra a violência de gênero etc. Para muitos estudiosos influenciados pela criminologia crítica, porém, essa mudança de rumo é desconcertante. A própria Larrauri (1992:217) manifesta sua surpresa "com a facilidade com que os movimentos progressistas recorrem ao Direito penal". Por sua vez, Bordelón (2003:453), adverte que a utilização do Direito Penal em atendimento aos apelos do movimento feminista acarreta a legitimação dos instrumentos repressivos característicos desse ramo do direito.

Larrauri (1992:194) assinala que de todos os desafios aos juristas críticos o mais contundente foi aquele proveniente do movimento feminista. Segundo a autora espanhola, as feministas evidenciaram que a gênese da opressão masculina não pode ser explicada apenas pelo surgimento e transformações do capitalismo, mas também pela emergência da sociedade patriarcal. Resumidamente, o ponto de vista feminista sobre a opressão (e, consequentemente, a violência) masculina exercida sobre as mulheres é o seguinte:

Determinados mecanismos como o medo da violência, a sexualidade, a ideologia que atribui um determinado papel à mulher na sociedade, etc., são mecanismos de controle social peculiares direcionados às mulheres. Todas essas particularidades próprias de uma sociedade patriarcal, a divisão de gêneros, as distinções entre a esfera pública e privada, as formas específicas de controle direcionadas à mulher, às suposições que rodeiam o discurso do delito e da vítima referidas à mulher, etc., são 
as que a criminologia crítica tinha passado por alto (Larrauri, 1992:194-195).

O raciocínio desenvolvido pelas feministas é de clareza meridiana: ao deslegitimar o Direito Penal ou, mais amplamente, o sistema penal, a criminologia crítica enfraquece a luta em favor da igualdade de gêneros e contra a sociedade patriarcal. Se o Direito Penal e o sistema penal existem e se, por outro lado, não existe qualquer evidência de que ambos se extinguirão em um futuro próximo tornase necessário que em o conteúdo desse ramo do direito e a atuação dessa instância oficial de controle social espelhem valores feministas e não valores machistas. Por conseguinte, a descriminalização de comportamentos violentos dos homens que atentam contra os direitos das mulheres só pode prejudicá-las (Larrauri, 1992:195). ${ }^{23}$ Explica-se assim a resistência das feministas diante de políticas-criminais descriminalizadoras que beneficiem os homens autores de violência de gênero.

Geralmente as feministas têm se mostrado reticentes em relação aos programas de ressocialização do homem agressor. Primeiramente, elas temem que esses programas reforcem a percepção de que a violência de gênero é um problema de natureza individual e não estrutural. As feministas também suspeitam que a ênfase concedida aos mencionados programas possam resultar em transferência de recursos que poderiam ser direcionados para as

${ }^{23} \mathrm{Na}$ verdade, não somente as feministas, mas também os ecologistas "argumentam que é ridículo que os setores mais débeis da sociedade - mulheres, estrangeiros, trabalhadores - sejam precisamente os que devem renunciar a utilizar o direito penal existente como meio de proteção" (Larrauri, 1992:218). 
vítimas. Por fim, elas advertem para o fato de que as esperanças despertadas pelos programas de ressocialização possam ser uma ilusão e que as vítimas, enganadas, continuem a submeter-se às agressões de seus companheiros por acreditar que eles mudarão de atitude. Em síntese, as feministas não acreditam na eficácia dos programas direcionados aos homens autores de violência e, ao mesmo tempo, acreditam que como alternativa à privação da liberdade tais programas reforçam a percepção social de que as agressões que eles cometem contra as mulheres são desimportantes (Larrauri, 2004:361-362).

A perspectiva punitivista do movimento feminista em relação à violência de gênero não está isenta de críticas, como deixa claro a doutrina jurídica espanhola.

Bordelón (2003:472) chama nossa atenção para o fato de que a utilização do Direito Penal no enfrentamento da violência de gênero é uma estratégia limitada porque se esgota na mera denúncia e no repúdio à violência masculina, deixando de levar em conta que o problema tem caráter estrutural, considerando-se que resulta da desigualdade nas relações de gênero e não de meros conflitos interpessoais. Bordelón (2003:481-482) recorda igualmente que a pena privativa de liberdade permanece como a principal modalidade de sanção penal e que as prisões abrigam uma quantidade maior de pessoas provenientes das camadas sociais marginalizadas. Por fim, a autora critica a estratégia punitivista adotada pelo movimento feminista porque, em contradição com seu próprio discurso, trata a violência de gênero como um problema individual entre agressor e 
vítima, desconhecendo dessa maneira a sua complexidade que dificilmente pode ser enfrentada pelo sistema penal. ${ }^{24}$

Desenvolvendo um raciocínio de certa maneira oposto ao exposto no parágrafo anterior por Bordelón, Medrado e Mello (2008:84) chegam a mesma conclusão a respeito da atuação do sistema penal nos casos de violência doméstica quando dizem que "a função punitiva não logra compreender os meandros de uma relação que descamba e em violência, nem serve como medida que inquiete os autores de violência impedindo-os de agir com violência por medo de punição". Porém, na opinião dos psicólogos a ineficiência do sistema penal no tratamento do problema da violência contra a mulher não decorre do fato de concebê-lo como uma questão individual. Segundo eles, “a punição não tem ajudado na 'prevenção' nem na compreensão da situação" porque a legislação não trata de maneira individualizada os casos de violência que lhe são submetidos.

Portanto, segundo os estudiosos que criticam a solução punitivista para o problema da violência de gênero e, em particular, da

${ }^{24}$ Referindo-se especificamente ao estupro como problema meramente individual, Bordelón (2003:483) afirma o seguinte: “As estruturas jurídicas do procedimento penal se caracterizam pela individualização do infrator. Dentro do procedimento penal a agressão sexual é reconhecida unicamente como a conduta concreta do agressor contra a vítima. Desta maneira, o conflito social que subjaz ao problema das agressões sexuais é reduzido a um problema de violência interpessoal, quando na realidade a questão da violência sexual deve ser compreendida numa perspectiva mais ampla [...] as análises feministas têm sublinhado a necessidade de se compreender o fenômeno do estupro no contexto dos papéis da conduta sexual masculina. 
violência doméstica, o encarceramento dos infratores e, mais amplamente, a aplicação de qualquer tipo de pena aos mesmos cumpre tão somente uma função simbólica consistente em chamar a atenção da sociedade para a submissão da mulher na sociedade patriarcal. O sistema penal é convocado a perseguir fins puramente pedagógicos por intermédio da atuação de suas múltiplas agências. Diante disso, o infrator torna-se ao final e ao cabo apenas um instrumento utilizado pelo sistema penal para viabilizar o surgimento de uma moral e comportamentos que permitam a superação da opressão machista e a transformação da sociedade com vistas a assegurar a igualdade de gêneros. Em síntese, o punitivismo feminista sacrifica no altar da luta justa pela igualdade de gêneros a promessa liberal do Direito Penal de garantias consistente em tutelar bens jurídicos mediante a pena. Mas essa não é a única crítica direcionada a essa visão punitivista.

Os estudiosos do problema da violência contra a mulher também alertam para o fato de que "o alto custo de manutenção das instituições prisionais, os resultados pouco animadores de seus procedimentos e eficácia, bem como a deslegitimação do sistema em virtude de uma seletividade social e econômica que deixa evidentes as desigualdades operadas pela justiça" (Romeiro, 2009:53).

Pesquisadores constataram que os críticos do punitivismo costumam afirmar que os problemas gerados pela sociedade patriarcal, a exemplo da dominação masculina e da violência de gênero, não podem ser resolvidos pelo sistema penal cuja intervenção nas relações conjugais serve apenas para exacerbá-los. Para esses críticos qualquer solução passa por uma intervenção direta sobre a pessoa do agressor visando modificar as suas atitudes, bem como a sua percepção acerca do relacionamento entre homem e mulher. Em nosso país, são poucos 
os programas de ressocialização que têm como alvo os homens autores de violência (HAV) (Northaft; Beiras, 2019). ${ }^{25}$

Beiras, Nascimento e Incrocci (2019:265) identificaram quarenta e um programas de ressocialização de homens autores de violência contra a mulher em todo território nacional. A maioria desses programas possui natureza híbrida, pois se vinculam aos órgãos estatais e, em particular, ao Judiciário estadual, o que não lhes assegura condições de funcionar a contento devido à escassez de recursos para a manutenção e ampliação de suas ações. Em consequência da ausência de autonomia econômica, os programas se submetem às diretrizes e expectativas oficiais. Os pesquisadores também constataram que os profissionais do direito que trabalham com a questão da violência doméstica, a exemplo de juízes e promotores, compartilham com os agressores a concepção patriarcal e machista das relações de gênero, o que lhes impede ter uma percepção acertada dos objetivos e estratégias dos programas de ressocialização (Beiras; Nascimento; Incrocci, 2019:268-271).

Northaft e Beiras (2019:7-8), por sua vez, documentaram as seguintes dificuldades enfrentadas pelos programas destinados à ressocialização dos homens agressores: (1) escassez de recursos; (2) ausência de coordenação entre as organizações não-governamentais (ONGs) que desenvolvem os programas; (3) falta de capacitação e supervisão dos profissionais dos programas; (4) alta rotatividade e

${ }^{25}$ Em 2016 esses programas existiam em apenas dez das vinte e sete capitais. Em alguns estados (Amapá, Goiás, Mato Grosso, Paraíba e Roraima) não existia nenhuma iniciativa do gênero (Northaft; Beiras, 2019:1-3). 
desistência dos participantes (agressores) nos programas cuja participação não é compulsória.

No que diz respeito às bases epistemológicas e teóricas dos referidos programas, os pesquisadores constataram que a maioria deles se baseia nas teorias de gênero, ou seja, que em sua maior parte tais programas adotam uma perspectiva eminentemente feminista nas ações que desenvolvem. ${ }^{26}$ Também em sua maioria, os programas preocupam-se com a responsabilização do homem autor de violência e em trabalhar para evitar a reincidência. Os métodos utilizados na avaliação dos programas variam, mas são produzidos relatórios periódicos elaborados pelas equipes escaladas para acompanhar os resultados. Estes resultados, entretanto, raramente são compartilhados, discutidos e divulgados em publicações acadêmicas. Essa omissão dificulta sensivelmente a avaliação global dos programas e a elaboração de estratégias destinadas a lidar com o problema da violência de gênero. Em suma, "os processos de monitoramento e avaliação representam um dos pontos nevrálgicos dos programas com

${ }^{26}$ Segundo Beiras, Nascimento e Incrocci (2019:272), as abordagens teóricas e epistemológicas dos grupos de discussão com os homens autores de violência exigem o "uso da perspectiva de gênero e de teorias feministas contemporâneas com abordagem crítica e reflexiva, que contemplem direitos humanos, igualdade de gênero, inteseccionalidades, diversidades e desconstrução do patriarcado, da homofobia e da transfobia são fundamentais para evitar a naturalização, banalização e legitimação social das violências de gênero e problematizar como os diferentes marcadores da diferença contribuem para as desigualdades sociais; ênfase em programas de caráter reflexivo ou psicoeducativo, e não terapêutico, para evitar uma perspectiva psicologizante ou patologizante da violência”. 
HAV no que diz respeito aos seus alcances e limitações" (Beiras; Nascimento; Incrocci, 2019:270).

Contudo, outros problemas também se fazem presentes no âmbito das estratégias não-punitivistas de abordagem do problema, a exemplo do escasso interesse dos agressores em participar dos programas de ressocialização. Tomando como base os discursos e as atitudes dos infratores, Northaft e Beiras (2019:6-8) identificaram as seguintes posturas reveladoras de uma resistência aos programas de ressocialização: (1) sentimento de que a Lei "Maria da Penha" é injusta porque privilegia as mulheres em detrimento dos homens; (2) dificuldade em reconhecer seu comportamento como violento ou tentar minimizar a violência cometida; (3) tendência a reconhecer apenas a violência física extrema como comportamento violento com a consequente exclusão da violência psicológica; (4) justificação da ação violenta em detrimento da narrativa da vítima. Os pesquisadores constataram que a maioria dos agressores não entende a razão pela qual foi obrigado a tomar parte no programa e se sente injustiçado por achar que não cometeu crime algum. Portanto, segundo eles, a primeira providência a ser tomada consiste em esclarecer os agressores sobre sua situação jurídica, bem como a diferença existente entre a natureza e os fins do programa e a natureza e os fins perseguidos pelo Judiciário.

Os dados produzidos pelos pesquisadores anteriormente referidos sugerem que as perspectivas não-punitivistas de enfrentamento da violência doméstica aparentemente não são animadoras, conclusão que pode reforçar mais ainda a estratégia punitivista de contenção desse tipo de violência. Mais adiante detalharemos nosso posicionamento a esse respeito, mas apenas depois 
de examinarmos o que as vítimas da violência doméstica pretendem quando a denunciam e solicitam providências às autoridades públicas. Em sua maioria, as mulheres vítimas de violência doméstica não querem que seus agressores sejam punidos criminalmente. Moraes e Sorj (2009:15) apuraram que "a vítima, em geral das classes populares, não está interessada em ingressar no mundo da lei, universal e impessoal". Na esteira do que já havia sido observado pelos pesquisadores nas últimas décadas do século anterior, ambos constataram que a mulher-vítima "se apropria do aparato policial de uma maneira peculiar para a mediação do conflito privado, o que não se enquadra na função primária da polícia penal que é de verificar e apura o crime". Segundo os pesquisadores, essa atitude "foi um resultado absolutamente imprevisível para as políticas de combate à violência de gênero" (Moraes; Sorj, 2009:16).

Silveira, Nardi e Spindler (2014:331-332) constataram em pesquisa realizada em Porto Alegre que a explicação para "o elevado número de arquivamento de processos, sem que nem mesmo a denúncia tenha sido feita pelo Ministério Público, é o desejo das vítimas se retratarem quanto à representação penal", atitude que, segundo os pesquisadores, evidencia o quanto a legislação em vigor é inefetiva no que tange à punição dos infratores. ${ }^{27} \mathrm{Na}$ pesquisa,

${ }^{27}$ Silveira, Nardi e Spindler (2014:331) fazem a seguinte observação sobre o recente estágio do embate entre as correntes punitivistas e não-punitivistas: "Nas questões de violência de gênero parece que o argumento do Direito Penal Mínimo, ou seja, aquele que defende uma postura menos punitivista, ganha maior guarida, sendo o discurso dos Direitos Humanos atualizado em prol do 'réu/homem/marido'. Nesse tipo de crime, emerge a compreensão jurídica de que o Direito Penal não seria o 
entrevistadas cem mulheres vítimas da violência doméstica e lhes perguntado o que esperavam da Delegacia da Mulher e do Poder Judiciário, as respostas não-punitivistas predominaram. ${ }^{28}$ As vítimas não pretendiam a punição do homem agressor, mas somente a intervenção de alguém com autoridade suficiente para evitar que sofressem novas agressões. Para os pesquisadores, a atitude dos operadores do direito que trabalham com esses casos contribuem para a impunidade porque não enxergam no agressor um criminoso, mas apenas um pai de família. Em suma, a hipótese dos pesquisadores é a de que o "arquivamento em massa dos processos judiciais" é provocado pelo "discurso conservador de dominação masculina, de preservação da família e da privacidade".

Em pesquisa realizada no Centro de Referência de Atenção à Mulher no Complexo de Favelas da Maré no Rio de Janeiro, os dados empíricos obtidos pelas pesquisadoras Santiago, Gonçalves e Augusto (2019:133) confirmam os resultados das pesquisas citadas nos parágrafos anteriores: em sua maioria as mulheres vítimas da violência doméstica não pretendem punir seus agressores. Os dados revelaram que muitas mulheres se recusam a registrar a ocorrência de violência, medida imprescindível para fruição das medidas protetivas

instrumento ideal para esse tipo de conflito doméstico, bem como a percepção do esgotamento do aparato estatal jurídico de 'punir' de forma efetiva esse tipo de 'agressor"'.

${ }^{28} \mathrm{O}$ artigo 16, da Lei "Maria da Penha" dispõe que "nas ações públicas condicionadas à representação da ofendida [...] só será admitida a renúncia à representação perante o juiz, em audiência especialmente designada com tal finalidade, antes do recebimento da denúncia e ouvido o Ministério Público". 
descriminadas na Lei "Maria da Penha". As mulheres vítimas "não querem registrar a ocorrência para não prejudicar o companheiro, muitas vezes pai de seus filhos e provedor da família, além do fato de muitos terem ligação com o tráfico de drogas na favela, o que poderia lhes causar ainda mais problemas". Na realidade, muitas vezes as vítimas sequer pretendem se separar de seus companheiros, mas apenas que eles parem de agredi-las. ${ }^{29}$ Em conclusão, Santiago, Gonçalves e Augusto (2019:137) assinalam a existência de "um descompasso entre os desejos da mulher e as estratégias criminais disponíveis".

Conclusão idêntica se faz presente nas pesquisas independentemente da unidade da Federação na qual ela é realizada. Em um município da região central do Paraná, por exemplo, constatou-se que "parcela significativa" das mulheres vítimas de

${ }^{29}$ A pesquisa realizada no Rio de Janeiro oferece duas explicações adicionais para o fato das vítimas da violência doméstica não recorrerem ao sistema penal com a finalidade de punir seus agressores: a presença na comunidade de organizações criminosas dedicadas ao tráfico de drogas e a descrença na capacidade dos aparelhos repressivos estatais enfrentá-las e fazer cumprir a Lei "Maria da Penha". A pesquisa revela que muitas vítimas da violência doméstica temem represálias por parte do tráfico caso recorram ao sistema penal em busca de proteção contra seus agressores e polícia tente entrar na comunidade, mesmo porque por vezes o próprio agressor integra a organização criminosa. Também não é raro que as próprias organizações criminosas proporcionem uma "justiça alternativa" às vítimas caso o infrator tenha violado algum de seus "mandamentos". Em conclusão, assinalam as pesquisadoras: "Quando as instituições legais falham e não dão conta de resolver problemas individuais e privados, a mediação do narcotráfico se apresenta como alternativa para os moradores desse território" (Santiago; Gonçalves; Augusto, 2019:135). 
agressão no âmbito doméstico pretendia inclusive voltar a viver com o agressor e também que por vezes a vítima "não busca puni-lo, mas deseja apoio para resgatar sua relação familiar em um convívio sem violência" (Madureira et alii, 2014:605). Na visão das pesquisadoras:

A violência contra as mulheres [...] provoca traumas de ordem física e psicológica, com consequências devastadoras, que afetam a saúde e que transcendem o aspecto biológico, de modo a comprometer as dimensões afetiva, social e profissional não apenas dos que a sofre, mas, da família como um todo. Assim, seu enfrentamento não pode se restringir ao combate, mas deve compreender, também, as dimensões da prevenção, assistência e garantia de direitos das mulheres. Por esta razão, requer do Estado e dos profissionais uma abordagem intersetorial e multidimensional, capaz de provocar mudanças culturais, educativas e sociais (Madureira, 2014:606).

Fica claro a esta altura que tanto a estratégia punitivista quanto a não-punitivista apresentam problemas, muitos dos quais de natureza estrutural. Simplesmente não há solução mágica para o problema da violência doméstica, o que deve ser considerado na elaboração das políticas criminais destinadas ao controle desse tipo de violência.

\section{REPENSANDO AS ALTERNATIVAS DE CONTROLE SOCIAL DA CRIMINALIDADE DOMÉSTICA.}

Pasinato (2015:421), uma das pesquisadoras pioneiras no estudo da violência de gênero no Brasil, afirma que a violência física e 
sexual contra a mulher é na maioria das vezes combinada com ofensas morais, ameaças e humilhações. Por essa razão a autora sugere que o profissional do direito "deveria compreender as categorias de violência em conjunto e como caracterizam o exercício desigual de poder que é definidor da violência baseada no gênero" e acrescenta: "As narrativas apresentadas pelas mulheres sobre a violência que sofreram apenas são reconhecidas a partir de sua classificação segundo os tipos penais e essa nem sempre é fácil, de forma que a demanda das mulheres fica muitas vezes sem efeito quando levada à polícia”, consequentemente, agrega a pesquisadora, "a violência é mais facilmente reconhecida quando deixa marcas, ou seja, quando ocorrem as lesões corporais e também a violência sexual". Em seu inconformismo, Pasinato afirma que quando questionados acerca da violência que se traduz em ofensas morais, ameaças e humilhações, os profissionais do direito demonstram enxergar superficialmente a violência psicológica, limitando-as às ações criminalizadas como ameaça, constrangimento ilegal e injúria. A autora não chega a dizer quais os crimes cometidos mediante violência psicológica que não são reconhecidos enquanto tais.

A censura formulada por Pasinato aos profissionais do direito evidentemente não tem razão de ser, revelando uma notável incompreensão acerca do caráter do Direito Penal de garantias característico do Estado Democrático de Direito. Embora seja indiscutível que todos os profissionais do direito, inclusive as mulheres, precisam ter uma compreensão ampla e suficientemente aprofundada acerca da violência de gênero, inclusive no que concerne às suas múltiplas manifestações, é necessário entender que o operador do Direito Penal deve pautar sua atuação pela legalidade. Significa dizer que por mais que ele perceba a importância da violência 
psicológica ou da violência moral cometida contra a mulher nenhuma intervenção do sistema penal pode ser admitida se a conduta do agressor não se subsumir a um tipo de injusto. Em suma, a violência psicológica em si não é crime a menos que a conduta do homem autor da citada espécie de violência ajuste-se integralmente a uma descrição típica, afirmação elementar para um jurista, mas que frequentemente não é bem compreendida pelo leigo.

Esse exemplo de mal entendido que pode surgir entre estudiosos do problema da violência doméstica e profissionais do direito demonstra como o estabelecimento de estratégias minimamente consensuais para o enfrentamento dessa modalidade de violência é complicado. Uma dessas dificuldades é muito evidente para os profissionais do direito cuja formação seja garantista: o Estado não é o remédio para todos os males sociais e ainda menos o seu sistema penal. Todo profissional do Direito Penal que tenha um mínimo de compromisso com o Direito Penal de garantias e que seja ao mesmo tempo um observador atento da realidade social tem condições de perceber no tocante à violência doméstica que esse ramo do direito deve ser considerado a derradeira ratio, isto é, deve ser reservado exclusivamente aos comportamentos capazes de causar um dano ou um perigo de dano aos bens jurídicos mais importantes que não possam ser protegidos por intermédio de alternativas extrapenais e mesmo extrajurídicas menos lesivas aos seus autores. Isso significa, em primeiro lugar, que somente as hipóteses de violência doméstica contra a mulher definidas como crimes sujeitam o agressor à sanção penal; em segundo lugar, que o legislador penal deve ter a preocupação de providenciar alternativas penais e extrapenais mais eficientes e menos lesivas ao agressor que a pena privativa de liberdade. 
Exame atento da Lei "Maria da Penha" revela que ela não contém nenhum mandato de criminalização, limitando-se a elencar as diversas modalidades de violência contra a mulher (física, psicológica, sexual, patrimonial e moral) e a prever "mecanismos para coibir e prevenir a violência doméstica e familiar contra a mulher", inclusive os existentes no Código Penal. Porém, por força do princípio da legalidade (artigo 5o, XXXIX, da Constituição da República e do artigo 1o, do Código Penal), a criminalização dos homens autores das citadas modalidades de violência depende da existência de norma penal incriminadora que as defina como crimes. Assim, por exemplo, a violência física que causa dano à integridade física ou à saúde da mulher pode caracterizar o crime de lesão corporal; a violência psicológica definida nos termos da Lei "Maria da Penha" pode traduzir crime de ameaça, constrangimento ilegal, cárcere privado etc.; a violência sexual pode denotar estupro, aborto, rufianismo, dentre outros delitos; a violência patrimonial, por sua vez, pode configurar apropriação indébita, furto, dano ou outros crimes; a violência moral pode indicar delitos contra a honra e assim por diante. Mas existem variadas manifestações de violência masculina cometidas contra as mulheres no âmbito doméstico que não são nem devem ser criminalizadas em homenagem ao caráter subsidiário do Direito Penal.

Mesmo correndo o risco de desagradar o movimento feminista nenhum profissional do direito com formação garantista discordaria da afirmação de que existe uma significativa variedade de manifestações de violência moral e psicológica cometidas pelos agressores contra suas companheiras que não devem ser criminalizadas. Por exemplo: a atitude do marido que rebaixa e ridiculariza a esposa acusando-a de não desempenhar a contento as 
tarefas domésticas caracteriza uma violência moral extremamente condenável. Mas se essa conduta não traduz um crime contra a honra o agressor não pode ser punido criminalmente. Ademais, o legislador penal não deve criminalizar essa violência moral por causa do caráter fragmentário e subsidiário do direito penal de garantias. Idêntica situação pode ser observada na conduta violenta do marido que vigia os passos de sua esposa, que escuta suas conversas particulares, que a ameaça com o divórcio, que a pressiona para que não mantenha contato com os amigos nem desfrute de sua companhia etc. Todos esses exemplos de violência moral e psicológica não devem ser objeto de intervenção penal, afinal, existem mecanismos jurídicos apropriados para que em todos esses casos a vítima da violência defenda sua liberdade se assim desejar, recorrendo, por exemplo, ao divórcio. Nesses casos, é o direito civil e, em particular, o direito de família e não o direito penal o instrumento jurídico mais legítimo e eficiente no sentido de coibir essas manifestações de violência doméstica e, ao mesmo tempo, de reparar seus efeitos sobre a pessoa da vítima, ao contrário do que acredita o movimento feminista.

Em um segundo plano, temos aquelas condutas cujos autores, em regra, não devem ser punidos com a privação da liberdade e nem mesmo, ao menos em princípio, com qualquer outro tipo de pena. São situações em que o comportamento do agressor causa dano ou perigo de dano a bens jurídicos de menor relevância ou quando causa dano de escassa importância a bens jurídicos relevantes. Em nosso sentir, a política criminal direcionada ao controle desses delitos não deve ser aquela proposta pelas feministas e que tem sido chancelada pelos tribunais. O artigo 41, da Lei "Maria da Penha", por exemplo, proíbe tanto a suspensão do processo como a reconciliação 
entre o réu e a vítima. Tribunais têm confirmado essa impossibilidade na esteira de uma política criminal que o movimento feminista tem considerado uma conquista na luta contra a violência de gênero e contra o patriarcado. Assim, abraçando o punitivismo, o Superior Tribunal de Justiça consolidou sua jurisprudência em duas súmulas cujo conteúdo é o seguinte: (1) "É inaplicável o princípio da insignificância nos crimes ou contravenções penais praticados contra a mulher no âmbito das relações domésticas". ${ }^{30}$ (2): "A prática de crime ou contravenção penal contra a mulher com violência ou grave ameaça no ambiente doméstico impossibilita a substituição da pena privativa de liberdade por restritiva de direitos". ${ }^{31}$

O espírito das mencionadas súmulas se compatibilizam com a orientação político-criminal do próprio Supremo Tribunal Federal, que também tem adotado um viés claramente punitivista no que diz respeito à violência doméstica, como deixa claro o seguinte acórdão:

Ementa. Habeas Corpus. Direito Penal. Contravenção Penal. Vias de Fato. Violência Doméstica contra a Mulher. Lei no 11.340/2006. Artigo 226, § 8o, da Lei Maior. Direitos Humanos da Mulher. Sistema Protetivo Amplo. Interpretação da Lei. Alcance. Infração Penal Crime e Contravenção. Combate à Violência em Todas as suas Formas e Graus. Substituição da Pena Privativa de Liberdade por Restritiva de Direitos. Inviabilidade. 1.

${ }^{30}$ Súmula 589. STJ. Terceira Seção. J. 13/09/2017. DJE. 18/09/2017.

${ }^{31}$ Súmula 588. STJ. Terceira Seção. J. 13/08/2017. DJE. 18/09/2017. 
Paciente condenado à pena de 20 (vinte) dias de prisão simples, em regime aberto, pelo cometimento da contravenção de vias de fato (artigo 21 do Decreto-Lei no $3.688 / 1941)[\ldots]$. 10. Ordem de habeas corpus denegada. ${ }^{32}$

Acreditamos, porém, contrariando a maior parte das feministas e dos tribunais, que nos casos de violência doméstica aos quais nos referimos anteriormente o caminho a ser trilhado não é o da punição, mas aquele que contribua mais efetivamente para a tutela de bens jurídicos e, secundariamente, para despertar nos homens autores de violência a consciência de que sua agressividade é inaceitável. Resumidamente, defendemos a opinião de que o tratamento a ser dispensado na maioria dos casos de violência doméstica deve ser restaurativo e não punitivo. ${ }^{33}$

Entretanto, para que o enfoque restaurativo possa ser coroado de êxito um problema básico precisa ser solucionado a priori: diante da extensão do problema da violência doméstica, os programas de natureza restaurativa implementados por organizações nãogovernamentais autônomas ou não necessitam de recursos humanos e econômicos. Há, portanto, necessidade de um compromisso estatal

${ }^{32}$ STF. Primeira Turma. HC 137.888 MS. J. 31/10/2017. DJE. 21/02/2018. Relatora Ministra Rosa Weber.

${ }^{33}$ A literatura existente acerca da justiça restaurativa é imensa e frequentemente trata de problemas relacionados à sua natureza, seu desenvolvimento, suas modalidades, seus problemas e resultados positivos. Recomendamos como obra introdutória o seguinte estudo: BRAITHWAITE, J. Restorative justice \& responsive regulation. Oxford: Oxford University Press, 2002. 
com a política criminal de caráter ressocializador, o que não ocorre atualmente, como comprovam as pesquisas citadas neste texto.

Além disso, ao contrário do que ocorre atualmente com os programas, as iniciativas restaurativas também precisam envolver as vítimas e não apenas os agressores. Procedimentos restaurativos não têm somente a função pedagógica transformar os homens autores de violência doméstica em seres humanos não machistas. Decerto essa função geral atribuída aos programas de ressocialização existentes reproduz uma preocupação até certo ponto legítima das feministas em não deixar que os casos de violência doméstica sejam tratados como problemas individuais quando, em última análise, eles têm natureza estrutural. Porém, essa perspectiva elimina toda esperança que agressores e vítimas possam ter de superar suas adversidades concretas, o que só se torna possível enfocando-se o problema particular que lhes diz respeito. $\mathrm{O}$ agressor e a vítima precisam compreender todas as dimensões do conflito por intermédio de um processo dialógico de cunho tanto emocional como simbólico que permita ao primeiro admitir sua responsabilidade na causação de danos físicos, psicológicos, morais e materiais à sua companheira e, ao mesmo tempo, demonstrar voluntariamente sua disposição de repará-los. Neste ponto, acompanhamos Larrauri (1994:216) quando ela diz ser importante que as alternativas à pena "não impliquem numa intromissão intolerável na personalidade do ofensor; que deem maior possibilidade de reparar o dano do delito; que deem maior participação dos envolvidos no conflito, etc.".

Evidentemente, para que o procedimento restaurativo se instaure é necessário que a vítima concorde em participar. Significa dizer que em nenhuma hipótese ela deve ser obrigada a fazê-lo, o que 
redundaria na denominada vitimização secundária, incompatível com uma visão liberal do sistema penal. E ainda mais: no curso do processo restaurativo deve ser assegurado a mulher vítima de violência doméstica a possibilidade de deixar de participar. Por exemplo: se ela percebe que o contato direto com o agressor é insuportável ou que o processo restaurativo não produzirá os resultados positivos, ela deve ter o direito de desistir. Portanto, a autonomia da vontade da vítima precisa ser preservada acima de qualquer outro interesse.

A possibilidade de não aceitar se submeter ao procedimento restaurativo ou mesmo de abandoná-lo durante sua execução também deve ser reconhecida ao agressor. Contudo, nesse caso o homem autor do crime contra a companheira deve ser penalmente responsabilizado pelo seu comportamento criminoso como qualquer outro infrator. Por conseguinte, a voluntariedade e o caráter consensual do processo restaurativo não diz respeito apenas à vítima, mas também ao agressor. Em relação ao homem agressor, acredita-se que o consentimento voluntário facilite a admissão de sua responsabilidade em relação à violência cometida, auxilie no diálogo com a vítima e viabilize a interiorização de valores não-machistas.

Em resumo, o processo restaurativo deve ser instaurado tão somente se o homem agressor e a mulher ofendida concordem com essa providência, o que significa dizer que nem os interesses do movimento feminista nem os do sistema penal devem sobrepor aos da vítima, considerando-se que esta última, como vimos anteriormente, almeja frequentemente somente a cessação das condutas violentas e não especificamente a punição do infrator.

Por último, na hipótese de ilícitos penais cometidos pelo homem autor de violência que causem lesão expressiva aos bens 
jurídicos mais relevantes, a exemplo do homicídio, da lesão corporal grave, do estupro etc., a imposição de pena ao agressor revela-se indispensável porque nesses casos a impunidade do infrator acarreta consequências extremamente graves que, inclusive, não atingem apenas a vítima, mas todas as potenciais vítimas da violência de gênero, vale dizer, às mulheres em seu conjunto. A impunidade desses crimes violentos representa sob o prisma simbólico uma espécie de "mensagem" contendo uma "autorização" aos homens para cometê-los, como se o sistema penal e a própria comunidade não se importassem e abdicassem das medidas necessárias à preservação da vida, da integridade física e da dignidade sexual. Mas existe outra razão igualmente importante que recomenda a responsabilização penal obrigatória do homem autor de crimes graves contra a mulher.

O Direito Penal de garantias justifica a repressão punitiva em nome da tutela de bens jurídicos. Infratores são penalmente responsabilizados na esperança de que ele ou terceiros não cometam novos crimes. Por vezes, entretanto, esquecemos que a proteção de bens jurídicos não engloba somente os interesses vitais do sujeito passivo do delito, mas também os do autor. A impunidade do homem autor do crime quando ele mata, ofende gravemente a integridade física ou estupra a mulher não raramente gera sentimento de vingança nos familiares da vítima ou na comunidade.

Martins (2015), maior estudioso brasileiro do fenômeno do linchamento, afirma que aproximadamente um milhão de pessoas participaram de pelo menos um linchamento tentado ou consumado nos últimos sessenta anos. De acordo com o autor, um dos fatores que resulta na citada prática delituosa é a carência de legitimidade do sistema penal provocada pela descrença em sua capacidade de cumprir 
as funções que lhe são atribuídas. Um sistema penal inoperante é, assim, um fator que estimula a sociedade a enveredar por caminhos alternativos no exercício do controle social, dentre os quais o linchamento dos autores ou, o que é frequente, dos supostos autores de crimes.

Martins (2015:51) esclarece que em muitos casos os linchadores "são movidos pela emoção de assumir o ponto de vista da vítima de um dano irreparável, diante do qual se tornou ou é impotente: num extremo, o assassinato e os estupros, por exemplo". Em todos os casos é a impunidade que ocupa um lugar central na motivação dos autores de linchamento: lincha-se porque há a descrença generalizada na capacidade e no interesse do sistema penal em punir o infrator que acabou de cometer o delito, mas lincha-se também por vingança, ou seja, porque esperava-se que o sistema penal punisse o infrator adequadamente, o que não ocorreu (Martins, 2015:91). Martins (2015:105) conclui desse modo que "em todos os casos é evidente, e não raro explicitamente dito, que a justiça pelas próprias mãos é praticada por descrença na justiça institucional". Cerqueira e Noronha (2004:171) acreditam, inclusive, que "a ação coletiva contra os crimes considerados 'bárbaros' pode, diante da omissão policial, se estender a todos os outros tipos de delito, independentemente da gravidade da ação".

Por tudo isso, a política-criminal destinada ao controle da violência doméstica em termos garantistas deve contemplar ao mesmo tempo a possibilidade de proporcionar o máximo de proteção às potenciais vítimas, inclusive mediante a criminalização dos infratores, e o mais alto nível de proteção a estes últimos contra modalidades alternativas ilegais de controle social, a exemplo dos linchamentos. 


\section{CONCLUSÃO: UMA POLÍTICA-CRIMINAL GARANTISTA DE ENFRENTAMENTO DA VIOLÊNCIA DOMÉSTICA.}

O problema da violência doméstica é complexo e por isso não comporta soluções simples. Quanto ao sistema penal, a pretensão punitivista das feministas em relação aos homens agressores possui conteúdo exclusivamente simbólico, colidindo assim com o direito penal de garantias que, consoante a doutrina dominante, encontra-se comprometido com a tutela de bens jurídicos. Em contrapartida, a inexistência de alternativas não-punitivistas concretas e eficientes capazes de compor o conflito entre as partes e contribuir para a superação da cultura machista característica da sociedade patriarcal estimula a reprodução da violência contra a mulher no âmbito doméstico numa espiral que reproduz incessantemente o crime e a impunidade. Diante disso, talvez seja importante evitar posicionamentos extremados do tipo "ou tudo ou nada".

Considerando o fato de que a violência doméstica comporta uma variada gama de manifestações (física, psicológica, sexual, moral e patrimonial) cada uma das quais capaz de consubstanciar uma multiplicidade de delitos muito diferentes entre si, nos parece evidente que intervenção do sistema penal não pode ser idêntica para todos os casos de violência cometida contra a mulher no âmbito doméstico. Há determinados comportamentos masculinos que, muito embora violentos, não são objeto da política criminal em sentido estrito ou, mas simplesmente, da política penal em decorrência do princípio da intervenção mínima. Por outro lado, em nosso sentir, nem toda agressão penalmente relevante deve implicar em imposição de pena. Quando se tratar de crimes de escassa gravidade o sistema penal 
deve privilegiar a via restaurativa no sentido da eliminação do conflito entre o agressor e a vítima desde que estes dois sujeitos adiram voluntariamente ao referido procedimento. Por fim, quando não se verificar a adesão de um dos sujeitos do delito ou quando se tratar de infração penal de maior gravidade recomenda-se a pena como alternativa preventiva de amplo espectro, inclusive com a finalidade de desestimular a vingança por parte dos familiares da vítima ou da própria comunidade, como na hipótese dos linchamentos.

\section{REFERÊNCIAS}

BEIRAS, A.; NASCIMENTO, M.; INCROCCI, C. Programas de atenção a homens autores de violência contra as mulheres: um panorama das intervenções no Brasil. Saúde e sociedade. São Paulo, v.28, n.1, p.262-274, jan./mar. 2019.

BIROLI, F. O público e o privado. In MIGUEL, L. F.; BIROLI, F. Feminismo e política: uma introdução. 1. ed. São Paulo: Boitempo, 2014, p.32-46.

BORDELÓN GONZÁLEZ, E. Género y sistema penal: los derechos de las mujeres en el sistema penal. In BERGALLI, R. (Coord.) Sistema penal y problemas sociales. Valencia: Tirant lo Blanch, 2003, p.451486. 
CASIQUE, L. C; FUREGATO, A. R. F. Violencia contra mujeres: reflexiones teóricas. Revista Latino-americana de Enfermagem. Ribeirão Preto, v.14, n.6, nov./dez. 2006.

CERQUEIRA, D.; BUENO, S. (Coords.). Atlas da violência. Brasília: Instituto de Pesquisa Econômica e Aplicada (IPEA), 2019.

CERQUEIRA, R. T. de; NORONHA, C. V. Cenas de linchamento: reconstruções dramáticas da violência coletiva. Psicologia em Estudo, Maringá, v.9, n.2, p.163-172, mai/ago, 2004.

GIDDENS, A. Sociologia. 8.ed. Trad. Alexandra Figueiredo et al. Lisboa: Fundação Calouste Gulbekian, 2010.

LARRAURI PIJOAN, E. La herencia de la criminología crítica. 2. ed. México: Siglo XXI, 1992.

LARRAURI, E. Es posible el tratamiento de los agresores de violencia doméstica? In LÓPEZ BARJA DE QUIROGA, J.; ZUGALDÍA ESPINAR, J. (orgs.). Dogmática y ley penal: libro homenaje a Enrique Bacigalupo. Madrid: Marcial Pons, 2004, t.1, p.359-380.

LAURENZO COPELLO, P. Violencia de género y el derecho penal de excepción: entre el discurso de la resistencia y el victimismo punitivo. In GARCÍA VALDÉS, C. et al (Coords.). Estudios penales en homenaje a Enrique Gimbernat. Madrid: EDISOFER, 2008, p.2093-2122, T.2. 
MADUREIRA, A. B. et alii. Perfil de homens autores de violência contra mulheres detidas em flagrante: contribuições para o enfrentamento. Escola Ana Nery: Revista de Enfermagem, s.l, n. 18 (4), out/dez, 2014, p.600-606.

MARTINS, J. de S. Linchamentos: a justiça popular no Brasil. São Paulo: Contexto, 2015.

MORAES, A. F.; SORJ, B. Os paradoxos da expansão dos direitos das mulheres no Brasil. In MORAES, A.; SORJ, B. (Orgs). Gênero, violência e direitos na sociedade brasileira. Rio de Janeiro: 7 Letras, 2009, p.10-22.

MEDRADO, B.; MELLO, R. P. Posicionamentos críticos e éticos sobre a violência contra as mulheres. Psicologia \& Sociedade, s.l., n.20, edição especial, p.78-86, 2008.

NORTHAFT, R. J.; BEIRAS, A. O que sabemos sobre intervenções com autores de violência doméstica e familiar? Revista de Estudos Feministas. Florianópolis, v.27, n.3, p.1-14, out. 2019.

PASINATO, W. Acesso à justiça e violência doméstica e familiar contra as mulheres: as percepções dos operadores jurídicos e os limites para a aplicação da Lei Maria da Penha. Revista de Direito GV. São Paulo, n. 11 (2), p.407-428, jul./dez, 2015.

PRADO, L. R.; CARVALHO, E. M.; CARVALHO, G. M. Curso de direito penal brasileiro. 13. ed. São Paulo: Revista dos Tribunais, 2014. 
ROMEIRO, J. A Lei Maria da Penha e os desafios da institucionalização da "violência conjugal" no Brasil. In MORAES, A. F.; SORJ, B. (orgs.). Gênero, violência e direitos na sociedade brasileira. Rio de Janeiro: 7 Letras, 2009, p.49-74.

SILVEIRA, R. Da S.; NARDI, H. C.; SPINDLER, G. Articulações entre gênero e raça/cor em situações de violência de gênero. Psicologia \& Sociedade. Belo Horizonte, v.26, n.2, p.323-334, mai/ago. 2014.

WAISELFISZ, J. J. Mapa da violência 2015: homicídio de mulheres no Brasil. 1.ed. Brasília: 2015. 